\title{
WILAYAH PELAYANAN PASAR MUARALABUH SEBELUM DAN SESUDAH DIPINDAHKAN LOKASI PASAR DI KECAMATAN SUNGAI PAGU KABUPATEN SOLOK SELATAN
}

\author{
Widia Pitri Yeni \\ Program Studi Pendidikan Geografi STKIP PGRI Sumatera Barat \\ widya_pitri28@yahoo.co.id
}

\begin{abstract}
Abstrak
Perubahan pemindahan pasar Muaralabuh pada dasarnya perubahan lokasi pasar dilakukan merupakan sebuah rangkaian dari proses sosial dan ekonomi. Penelitian ini bertujuan untuk mendapatkan data, mengolah, menganalisis dan membahas tentang Wilayah Pelayanan Pasar Muaralabuh Sebelum dan Sesudah Di pindahkan di Kecamatan Sungai Pagu dilihat dari: 1) wilayah pelayanan, 2) tingkat pendapatan, 3)sarana dan prasaranan. Penelitian ini tergolong pada penelitian deskriptif. Populasi penelitian ini adalah masyarakat yang berada di sekitar pasar yang terdiri dari dua jorong, yaitu jorong Kampung Palak dan jorong Rawang, pedagang/penjual, pembeli, tukang kebersihan, tukang ojek, dan benjual jasa. Sampel penelitian diambil secara proporsional random sampling yaitu mengambil sampel secara acak dengan proporsi $20 \%$ sehingga jumlah responden dalam penelitian ini berjumlah 159 KK.Sampel responden adalah kepala keluarga yang terdapat di Kecamatan Sungai pagu Kabupaten Solok Selatan yang mempunyai aktivitas langsung dan tidak langsung dengan kegiatan pasar di Kecamatan Sungai Pagu.

Hasil penelitian menemukan: 1) Wilayah pelayanan pasar sebelum dan sesudah dipindahkan di Kecamatan Sungai Pagu pada umumnya baik, 2) Tingkat pendapatan masyarakat dilihat dari pendapatan dan pengeluaran selama satu bulan sebelum dipindahkan pasar kurang baik(Rp,600.000-1.000.000 , sedangkan sesudah dipindahkan pasar pada umumnya baik ( $\geq$ 2.000.000,00, 3) Sarana dan Prasarana sebelum dan sesudah dipindahkan pasar Muaralabuh di Kecamatan Sungai Pagu dilihat dari kelengkapan sarana dan prasarana pada umumnya lengkap.
\end{abstract}

\section{PENDAHULUAN}

Pasar merupakan tempat berkumpulnya orang-orang yang melakukan transaksi barang dan jasa. Penjual dan pembeli datang ke pasar dengan tujuan mengadakan pertukaran untuk memenuhi kebutuhannya.Membahas masalah pasar merupakan hal yang penting untuk dilakukan, karena dalam kehidupan manusia keberadaan pasar memegang peranan yang amat penting dalam menunjang pemenuhan kebutuhan manusia.Sesuai dengan kodratnya sejak dilahirkan di muka bumi manusia telah memiliki kebutuhan. Pada awalnya kebutuhan itu masih bersifat sederhana namun lama kelamaan dengan semakin majunya teknologi maka kebutuhan manusia atau masyarakat semakin banyak pula (Deliarnov,1995).

Perubahan pemindahan Pasar Muaralabuh di Kecamatan Sungai Pagu Kabupaten Solok Selatan adalah pada dasarnya perubahan lokasi pasar dilakukan 
merupakan sebuah rangkaian dari proses sosial dan ekonomi. Sesuatu yang berhubungan dengan perubahan-perubahan kondisi meliputi perubahan dalam organisasi masyarakat, persepsi masyarakat, gaya hidup dan kepuasan yang diakibatkan karena adanya pembangunan. Membuat pedagang mengalami perubahan pendapatan karena banyak persaingan dan pertumbuhan jumlah pedangang, pemerintah daerah juga mendapatkan peningkatan pendapatan hasil dari biaya distribusi yang dipungut setiap hari pasar karena adanya pertumbuhan jumlah pedagang dan biaya sewa tempat berdagang.

Tahun 2003 terjadi pemekaran Kabupaten Solok yang mengakibatkan lahirnya Kabupaten Solok Selatan.Pemekaran ini berimbas terhadap peningkatan pedangang Pasar Muaralabuh menjadi meningkat jumlah pembelian, maka untuk itu diperlukan sarana yang memudahkan mereka dalam melakukan jual beli di Pasar Muaralabuh.Pasar Muaralabuh merupakan tempat jalur lalu lintas antara Kerinci (Jambi), Dharmasraya dan Padang. (Deliarnov,1995).

Pasar Muaralabuh merupakan sebuah pasar Nagari wujud dari pertumbuhan Solok Selatan.Menjadi sumber pendapatan asli daerah, keberadaan Pasar Muaralabuh memberikan dampak yang besar, bagi masyarakat yang tinggal di sekitar pasar tersebut.Di Bidang Sosial-Ekonomi keadaan Pasar Muaralabuh memberikan lapangan kerja bagi masyarakat yang tinggal di sekitar pasar.

Hari pasar Muaralabuh yang berlangsung setiap hari Senin dan Kamis, banyak orang berdatangan dari berbagai daerah yang ada di Kabupaten Solok Selatan, seperti Kecamatan Koto Parik Gadang diAteh (KBGD), Kecamatan Alam Puah Duo, Kecamatan Sangir, termasuk Kota Solok dan lain-lain. Pasar Muaralabuh merupakan salah satu pasar yang dekat dengan pemukiman penduduk, mudah dijangkau oleh masyarakat.Para pedagang yang berasal dari berbagai daerah tersebut saling berhubungan dan berinteraksi dengan berbagai kepentingan.Selain mengadakan transaksi jual beli mereka juga saling bertukar informasi.

Tahun 2009 Penetintaan Daerah memindahkan pasar Muaralabuh kelokasi lain, karena pasar yang ada sudah mengalami penyempitan dan tidak 
memungkinkan lagi untuk diadakan peluasan pasar. Pasar Muaralabuh yang baru dipindahkan tidak jauh dari lokasi pasar sebelumnya.

Pasar Muaralabuh merupakan pasar tradisional yang terdapat di Kecamatan Sungai Pagu Kabupaten Solok Selatan identik dengan kondisi yang tidak beraturan dan kurangnya kenyamanan, sehingga salah satu usaha agar pasar tradisional tetap bertahan perlu pembenahan di beberapa aspek salah satunya pelayanan.

\section{METODOLOGI}

Berdasarkan latar belakang masalahpenelitian dan tujuan penelitian.Jenis penelitian ini tergolong penelitian deskriptif. Populasi penelitian ini adalah Berdasarkan dari defenisi diatas dan disesuaikan dengan permasalahan yang diajukan maka yang menjadi populasi dalampenelitian ini adalah masyarakat Kampung Palak dan Rawang yang berada disekitar Pasar Muaralabuh. Pengambilan sampel respon dan dalam penelitian ini dilakukan dengan menggunakan teknik proporsional randam sampling, yaitu mengambil sampel secara acak dengan proporsi $20 \%$ sehingga jumlah responden dalam penelitian ini berjumlah 159 KK. Sampel penelitian adalah kepala keluarga yang terdapat di sekitar Pasar Muaralabuh yang mempunyai aktivitas langsung dan tidak langsung dengan kegiatan Pasar Muaralabuh Kecamatan Sungai Pagu.

\section{PEMBAHASAN}

Pada pembahasan ini akan dibahas hasil penelitian tentang Wilayah Pelayanan Pasar Muaralabuh Sebelum dan Sesudah dipindahkan Lokasi Pasar di Kecamatan Sungai Pagu Kebupaten Solok Selatan yang meliputi Wilayah Pelayanan, Tingkat Pendapatan dan Sarana dan Prasarana. Berdasarkan deskriptif data di atas, maka dapat dijelaskan babwa:

Pertama.Hasil penelitian yang telah dilakukan di lapangan bahwa wilayah pelayanan pasar Muaralabuhsebelum dipindahkan pasar Muaralabuh pada umumn kurang baik sedangkan sesudah dipindahkan wilayah pelayanan pasar umumnya baik. Jarak tempat tinggal pedagang dengan lokasi berdagang mempengaruhi pemilihan tempat bergadang, pedagang tidak sangkup untuk 
mencari lokasi yang jauh karena dalam mencapai lokasi berdagang memerlukan ongkos pengangkut (biaya transportasi).Mela Mardani (2013).

Kedua: Berdasarkan penelitian yang telah dilakukan dilapangan bahwa tingkat pendapatan masyaraka dilihat dari pengeluaran selama satu bulan sebelum umumyan tetap sedangkan sesudah dipindahkan umumnya meningkat, dan pendapatan selama satu bulan sesudah dipindahkan pasar pada umumnya sebelumtetap, sedangkan pengeluaran selama satu bulan sesudah dipindahkan umunnya meningkat.

Temuan ini sama dengan Elvia dalam putri (2012) menyarakan bahwa: pendapatan adalah sumber dasar bagi keluarga untuk menentukan tingkat pengeluaran tiap-tiap keluarga, dimana tingkat pendapatan tiap-tiap keluarga itu akan berbeda-beda. Namun sebelum dan sesudah dipindahkan pasar tingkat pendapatan masyarakat di kecamatan sungai pagu masih tetap sama, hal ini dikarenakan sebelum dipindahkan pasar masyarakat sungai pagu sebelumnya masih perdagang dalam keadaan pasarnya sempit.

Ketiga :Berdasarkan penelitian yang telah dilakukan dilapangan bahwaKondisi sarana dan prasarana di lihat dari sebelum dan sesudah, pasar sebelum dipindahkan dengan kondisi sarana umumya kurang memadai sedangkan pasar sesudah dipindahkan dengan kondisi sarana umumnya memadai dan kondisi prasarana sebelum dipindahkan umumnya kurang baik, sedangkan kondisi prasarana pasar sesudah dipindahkan umunya memadai. Teman ini sama dengan Oktavani dalam Novia (2012), memaparkan bahwa sarana adalah fasilitas yang menghasilkan produk dan jasa-jasa secara langsung dibutuhkan, sedangkan prasarana adalah segala sesuatu yang merupakan penunjang utama untuk terselenggaranya proses.

\section{KESIMPULAN}

Berdasarkan hasil penelitian dan pembahasan maka, diambil kesimpulan sebagai berikut:

1. Hasil penelitian yang telah dilakukan di lapangan bahwa wilayah pelayanan pasar Muaralabuh sebelum dipindahkan pasar Muaralabuh pada 
umumn kurang baik sedangkan sesudah dipindahkan wilayah pelayanan pasar umumnya baik

2. Berdasarkan penelitian yang telah dilakukan dilapangan bahwa tingkat pendapatan masyaraka dilihat dari pengeluaran selama satu bulan sebelum umumyan tetap sedangkan sesudah dipindahkan umumnya meningkat, dan pendapatan selama satu bulan sesudah dipindahkan pasar pada umumnya sebelum tetap, sedangkan pengeluaran selama satu bulan sesudah dipindahkan umunnya meningkat.

3. Berdasarkan penelitian yang telah dilakukan dilapangan bahwaKondisi sarana dan prasarana di lihat dari sebelum dan sesudah, pasar sebelum dipindahkan dengan kondisi sarana umumya kurang memadai sedangkan pasar sesudah dipindahkan dengan kondisi sarana umumnya memadai dan kondisi prasarana sebelum dipindahkan umumnya kurang baik, sedangkan kondisi prasarana pasar sesudah dipindahkan umunya memadai. 


\section{DAFTAR PUSTAKA}

Arikunto, Suharsimi. 2006. Prosedur Penelitian. Jakarta: Rineka Cipta

Damsar. 2005. Sosiologi Pasar. Padang: Laboratorium Sosiologi FISIP Unand.

Deliarnov. 1995. Perkembangan Pemikiran Ekonomi. Jakarta: Raja Grafindo Persada.

Elvia. 2012. Perubahan Sosial Ekomoni Masyarakat Sesudah Pengembangan Objek Wisata Pembandian Lembah Segar Jorong Siguhung Kecamatan Lubuk Basung Kabupaten Agam.Skripsi. Padang: STKIP PGRI.

Mela. 2013. Kondisi Sosial Ekomoni Dan Lingkungan Masyarakat Sebelum Dan Sesudah Pembangunan Pasar Di Nagari Talaok Kecamatan Bayang Kabupaten Pesisir Selatan. SkripsI. Padang: STKIP PGRI.

Novia. 2012. Perubahan Sosial Ekomoni MasyarakatSesudahPengembangan Objek Wisata Pembandian Lembah Segar Jorong Siguhung Kecamatan Lubuk Basung Kabupaten Agam.Skripsi. Padang: STKIP PGRI.

Sugiyono. 2011. Metode Penelitian Pendidikan Bandung: Alfabeta.

Tika,Pabundu. 2005. Metode Penelitian Geografi. Jakarta: Bumi Aksara. 